\title{
И.Е. Рогаева
}

\section{СОВРЕМЕННАЯ АМЕРИКАНСКАЯ ИСТОРИОГРАФИЯ ОБ ИСТОРИИ КОЛОНИЙ НОВЫЙ ПЛИМУТ И МАССАЧУСЕТС В ХVІІ в.: ЭКОЛОГИЧЕСКОЕ ИЗМЕРЕНИЕ}

\begin{abstract}
Работа посвящена анализу современной американской историографии первых английских колоний Новой Англии с точки зрения экологической истории. Американская традиция экологической истории новоанглийских поселений рассматривается как многомерный феномен, связанный с изучением взаимодействия человеческого социума и природы в качестве единого хозяйственно-культурного комплекса. Автор исследует историографию экологических аспектов колонизации региона с позиций столкновения европейской и индейской культур, образов жизни и способов взаимодействия с экосистемой.

Ключевые слова: Американская историография; экологическая история; Новый Плимут; Массачусетс; экосистема.
\end{abstract}

Экологическая история, или история окружающей среды, изучает взаимодействие человека с природой в исторической динамике. В США, на родине экологической истории, этот подход получил популярность в последнюю четверть XX в. под влиянием общественных движений в защиту окружающей среды [1]. Экоистория рассматривает человека и природу в комплексе - во взаимосвязи и взаимовлиянии. Окружающая среда - результат этого взаимодействия, следствие трансформации природы человеком. Центральным понятием экологической истории является экосистема, лаконичное определение которой дал Э. Ле Руа Ладюри. Экосистема по Ладюри - это «природа плюс сельское хозяйство, фауна, бациллярная флора плюс человеческий род» [2. С. 161].

Воздействие исторической экосистемы на человеческое сообщество, его социальный, культурный, экономический и политический уклад, а также анализ трансформации экосистем социумом является основой исследовательской стратегии экоистории [3. Р. 249]. Изучение «прошлого» самой природы, будучи уделом естественных наук, не относится к задачам экологической истории, поскольку «природа не нуждается в людях, в то время как окружающая среда появляется только там, где живут люди и где люди вступают в отношения с окружающим их миром» [4. Р. 3]. Природа в этих отношениях выступает в качестве такого же актора, как и социум, а социальная сущность человека рассматривается в контексте естественных биологических характеристик.

В идеях американской школы экоистории заметно влияние двух исследовательских традиций. Первая из них - это история фронтира и американского Запада, которая опирается на работы Фредерика Дж. Тернера [5], Уолтера П. Уэбба [6] и Джеймса Малина [7]. Тернер, а вслед за ним Уэбб, поместили окружающую среду в центр повествования о становлении и развитии американских общественных институтов. Джеймс Малин подверг ревизии концепции Тернера и Уэбба, критикуя последних за экологический детерминизм и отрицая решающее влияние ландшафта, климата и осо- бенностей почвы на формирование общественного уклада [8]. Он подчеркнул сложность и взаимозависимость отношений между социальными устоями и физической средой. Малин заявил, что культура формируется в результате адаптации человека к новой для него среде и залог успеха этой культуры - в поддержании баланса с природным миром [7. Р. 327-330].

Вторая традиция восходит к представителям французской школы «Анналов»: Фернану Броделю и упоминаемому выше Эммануэлю Ле Руа Ладюри. Бродель отвел первый том исследования Средиземноморья XVI в. «почти неподвижной истории, истории человека в его взаимоотношениях с окружающей средой» [9. С. 20]. Бродель - один из первых историков, который возвел окружающую среду в ранг действующего лица истории. Он продемонстрировал, как физикогеографическое единство ландшафта и климата влияло на жизненный уклад общества. «Сезонный детерминизм» вмешивался не только в график полевых работ, животноводства и навигации, но и в деятельность банков, сворачиваемую зимой, работу ремесленников, оживлявшуюся в холодное время года. Времена года вносили коррективы в вопросы войны и мира: «...зима - это время переговоров, дипломатических встреч, мирных намерений» [9. С. 351] в противовес лету - периоду войн, мятежей и эпидемий. Теплому сезону в Средиземноморье неизменно сопутствовала малярия, очагом которой были болотистые равнины. Вспышки чумы, привнесенной в регион извне, также приходились на лето - период активной мобильности населения. Наибольшую опасность эпидемии представляли для крупных городов, в которых, в условиях высокой плотности населения и низкого уровня гигиены, болезни распространялись быстро. Богатые жители летом устремлялись на свои загородные виллы, покидая инфицированные города и своих менее обеспеченных сограждан. Жизнь общества была зависима от окружающей среды, но в то же время социум трансформировал природу, подчиняя ее своим нуждам. Покоренное человеком море, прежде бывшее преградой для общения, способствовало «установлению связей, 
постепенному формированию стройной целостности Средиземноморья, принадлежащего людям и истории» [9. С. 323].

Э. Ле Руа Ладюри в «Истории климата с 1000 года» [10] сместил фокус исследования с фигуры человека на историю окружающей среды. Ладюри предложил работу, в которой климат был впервые изучен «сам по себе в историческом плане, а не в “экологическом" по отношению к человечеству» [Там же. С. 11]. Ладюри рассматривает формирование истории климата, свободной от антропоцентризма, в качестве первого этапа исследования, еще более масштабного, предполагающего естественное слияние климатической истории и истории человечества. Результатом должно было стать рождение исторической экологии [Там же. С. 21-22]. В «Истории климата» Ладюри не ставит себе задачу перейти на этот «второй этап» работы. После значительного перерывы, в 2000-х гг. он вновь обращает свое внимание на проблемы экоистории и переходит к изучению влияния климатических флуктуаций на европейскую историю в цикле работ, включающем трехтомный труд «Человеческая и сравнительная история климата» [11-13] и книгу «Тридцать три вопроса об истории климата» [14]. В этих исследованиях Ладюри интегрирует события климатической истории в историю социума в качестве некой «базы данных», обращение к которой позволяет переосмыслить такие элементы человеческого прошлого, как эпидемии, войны, голод, народные волнений и демографические кризисы с позиций экоистории.

Ранняя колониальная история Северной Америки в фокусе экологической истории приобрела новые грани. Актуализировались вопросы, которые, казалось бы, и без того имеют давнюю историю изучения в американской историографии: проблемы генезиса первых европейских поселений в Новом Свете, колониальные столкновения, фронтир, взаимодействие с коренным населением, специфические черты материальной культуры и социально-экономических укладов. Экоистория, предлагая новые подходы к изучению внешне знакомых сюжетов, раскрывает в них новые смыслы. В то же время, стремясь выявить ускользающие от глаз историков взаимосвязи между природным и социальным миром, она ставит на повестку дня новые вопросы, не характерные ранее для исторических исследований: болезни, вирусы, эпидемии, или океан как часть исторической экосистемы. Откликаясь на общий дрейф исторической науки к проблематике символических форм, исследование «мест памяти» ${ }^{1}$ в культуре индейцев также становится частью многогранной экологической истории.

Работой, во многом задавшей вектор современной экоистории в изучении первых колоний, стала книга Уильяма Кронона «Изменяя землю: индейцы, колонисты и экология Новой Англии» [15], которая выдержала несколько изданий с 1983 по 2003 г. Кронон посвятил книгу анализу и интерпретации культурных и эко- логических последствий колонизации Новой Англии. Два аспекта этой работы позволяют взглянуть на архетипичные сюжеты колониальной истории под новым углом.

Первый аспект показывает широту воздействия на окружающую среду противоположных представлений о собственности, характерных для англичанпилигримов и коренных американцев. Английское право наделяло владельца земли всей полнотой власти над ней: право владеть, продавать, дарить, использовать ее ресурсы по своему усмотрению. В глазах индейцев взаимоотношения с землей, напротив, строились на принципах «узуфрукта» - права владеть не землей, а плодами, которые она приносит, жить на земле, возделывать ее, но не распоряжаться ею [15. Р. 72]. Истинная причина конфликта между индейцами и колонистами-пилигримами, по мнению Кронона, крылась именно в разном отношении к окружающей среде и обусловленном этими принципами ведении хозяйства, а не в борьбе за ресурсы.

Вторым аспектом стало переосмысление степени воздействия американских индейцев на экосистему региона. Еще Джон Бейклесс в работе «Америка глазами первооткрывателей» (1969 г.) [17] реконструировал ландшафты восточного побережья Северной Америки в доколониальную эпоху, опираясь на сохранившиеся письменные свидетельства путешественников и первых европейских переселенцев. Регион предстает в этом исследовании изобильным нетронутым лесом, «за исключением участков, расчищенных индейцами под посевы, и редких лугов» [Там же. С. 209]. Кронон, опираясь на «отчеты» и письма первых колонистов, работы историков и современные труды экологов, пришел к выводу, что уже до прибытия европейцев индейцы воздействовали на экологию, занимаясь охотой и сельским хозяйством, пусть и менее влиятельным способом, чем англичане: будущая Новая Англия накануне колонизации технологически соответствовала «каменному веку». Аборигены оказывали влияние на экосистему, но, поскольку их технологические возможности были невелики, а численность населения оставалась сравнительно небольшой, общее вмешательство индейцев в экологию Северной Америки было незначительным.

Книга Кронона оказала сильное влияние на последующие исследования как истории Нового Плимута и Массачусетса, так и колониальной истории США в целом, формируя новый тренд экологической истории. Кронону удалось показать, что экосистема не бывает инертной, она чутко реагирует на любое воздействие, которое оказывает на нее человек. Роль стабильности и оседлости в европейском способе ведения хозяйства обусловил возникновение нового режима собственности на землю в первых колониях, который ограничил возможности взаимодействия с экосистемой для коренного населения и глубоко отразился на экологии региона в целом.

В работе У. Джеффри Болстера фокус экоистории сместился с континентальных ракурсов на просторы 
океана. Его статья «Включение океана в историю Атлантики: морские сообщества и экология моря в северо-западной Атлантике, 1500-1800 гг.» [18] подняла вопрос изучение экосистем океана во взаимосвязи с историей человечества. Болстер называет период с 1500 по 1800 г. «эпохой Океана», в которой океан является крупнейшей магистралью, основой торговли, источником пищи, подателем материальных благ. Концентрируясь на просторах Атлантики вдоль северовосточного побережья Северной Америки от Ньюфаундленда до мыса Кейп-Код, автор замечает, что в указанный период эта территория стала важным перекрестком, точкой взаимодействия коренного населения Америки, колонистов и странствующих европейцев.

Мотив изобильных вод северо-западной Атлантики настойчиво звучит в сочинениях первых колонистов и их предшественников - европейских мореплавателей. Рыба занимала значимое место в рационе христиан. Примерно треть года католики и протестанты были ограничены в потреблении мяса из-за религиозных постов. На протяжении Средневековья жители Британских островов отдавали предпочтение пресноводной рыбе, вылов которой был более легким в сравнении с морским промыслом. С течением времени растущее население оказывало все большее влияние на обитателей пресных водоемов. Вырубка лесов, строительство плотин, сточные воды, загрязненные отходами животноводства и промышленности привели к деградации пресных водных ресурсов. После истощения рек и озер, англичане приступили к морскому рыболовству. Болстер отмечает, что Атлантический мир, в котором доминируют европейцы, в немалой степени сложился из-за их «ненасытных требований, предъявляемых к экосистемам Бискайского залива, Ла-Манша и Северного моря» [Ibid P. 28]. Подверженные колебаниям ресурсы европейских морей не всегда могли удовлетворить потребности населения, живущего на его берегах, что и побудило рыболовов к расширению географии промысла.

Пилигримы стремились к восточному побережью Северной Америки не только за духовной свободой, но и в поисках трески, которая, по слухам, в изобилии водилась в здешних водах. Отмели Кейп-Кода славились запасами осетровых, которые практически исчезли в метрополии. Огромную ценность для жителей региона представляли киты, свободно жившие у берегов полуострова. Китовый жир использовался для освещения, как смазочное вещество, находил применение в медицине, мыловарении, китовое мясо шло в пищу, что делало китобойный промысел источником стабильного сезонного дохода.

Болстер замечает, что богатство прибрежных вод Новой Англии было относительным и проявлялось в сравнении с истощенными европейскими водными экосистемами. Природное изобилие восточного побережья Америки XVI-XVII вв. предопределялось не климатическими условиями, а меньшим числом населения с менее развитой материальной культурой. Через сто лет после основания Нового Плимута и Массачу- сетса количество жителей в обеих колониях приблизилось к ста тысячам человек. Уровень населения практически сровнялся с количеством индейцев, обитавших в регионе до контакта с европейцами. Океаническая экосистема, тем не менее, подвергалась эксплуатации человеком в значительно большей степени, чем в доколониальную эпоху. Численность осетровых была недостаточна для открытого промысла уже к 1673 г. - через 50 лет после начала массового вылова европейцами этой рыбы [18. Р. 38]. По данным Болстера, в период с 1696 по 1734 г. колонистами были истреблены от 2459 до 3025 китов от залива Делавэр до штата Мэн [Ibid. P. 34]. Болстер связывает с китобойным промыслом колонистов вымирание популяции серых китов, живших у восточного побережья Северной Америки. В местных водах снизилось число трески, полосатого окуня, лосося. К 1800 году морская экосистема региона была значительно преобразована в результате локальных изменений, трансформации устьев рек, истребления морской фауны и уже мало отличалась от европейских морей. Эти процессы отразились на жителях прибрежного региона, вызвав экономические трудности. Кризис был преодолен, в частности с помощью технологических инноваций и географических исследований, что привело, как пишет Болстер, к изменению социальной идентичности жителей Новой Англии [Ibid. P. 25].

Исследуя взаимосвязи между океаном и людьми, история океанической экосистемы в интерпретации Болстера предлагает переосмыслить географические и социальные границы, опираясь на концептуальные достижения морской экологии. Изучение документальных и археологических свидетельств колониальных поселений в свете подходов экологии моря способствует исторической реконструкции единой экосистемы и включению океана в пространство исторических исследований.

Кристин М. Делусия в статье «В поисках Киккемуита: водные источники, каменные мемориалы и борьба за место обитания на северо-восточной границе» [19] затрагивает водную проблематику в ином, символическом контексте. Эта работа посвящена «местам памяти» в истории окружающей среды. Ее отправной точкой является природная достопримечательность - источник Киккемуит на берегу залива Наррангасетт. Киккемуит часто упоминается в контексте конфликтов между индейцами вампаноагами и поселенцами Плимутской колонии, переросших в войну местного вождя «короля Филиппа» против английских колонистов и их индейских союзников в конце XVII в. Работа Делусии направлена на выявление материального и символического значения ручья Киккемуит в истории этого столкновения.

Источники пресной воды в непосредственной близости от океанического побережья были жизненно важны как для Плимутской колонии, так и для индейцев. В этом суть материального значения Киккемуита [19. Р. 478]. Его символическое значение кроется в 
особенностях мировоззрения колонизаторов и коренных американцев. Основатели Плимута - ортодоксальные пуритане, воспринимавшие библейский текст подчас буквально. Религиозное сознание пуритан наделяло водные источники сакральным смыслом, отсылая к блужданию в пустыне ведомых Моисеем израильтян. В индейской традиции водные объекты часто становились маркерами границ, пунктами для встреч, реперами символических воспоминаний о неких важных событиях. Это были ориентиры «природной летописи» индийской истории, находящей отражение в племенных преданиях. Колонизация региона постепенно ограничивала доступ индейцев к местам, подобным ручью Киккемуит. Вместе с этим постепенно исчезала память о вехах индейской истории.

В рассуждении Делусии о пространстве и времени ручьи, камни, деревья выступают в качестве маркеров многовековой истории, сплетая воедино историю и географию. Обращение к таким «местам памяти» как Киккемуит помогает увидеть альтернативное прошлое и альтернативное понимание исторического процесса по отношению к письменной традиции англоамериканских поселенцев. Сложность заключается в том, чтобы отыскать их следы в письменных источниках и в современном ландшафте США.

Таким образом, автор помещает Киккемуит в широкий региональный контекст, сравнивая его с аналогичными, вписанными в ландшафт «местами памяти» Новой Англии. Делусия отмечает, что исследование истории окружающей среды невозможно совершить в отрыве от верований и традиций исследуемых народов. Необходимо учитывать зависимость этих верований от современных им экологических реалий.

Мэри Э. Стин в статье «Строительство в климатических условиях Нового Света: влияние культуры или окружающей среды?» [20] анализирует превращения типичного английского дома, построенного по модели hall-and-parlor (холл и гостиная), в жилище колонистов, именуемое saltbox (солонка). Стин прослеживает, какие культурные и экологические факторы повлияли на изменение форм жилых строений в Новом Плимуте и Массачусетсе. Стин опирается на данные археологии и документальные источники о жизни английских пуритан по обе стороны Атлантики. Анализ дополняют современные данные климатологии, которые автор экстраполирует на исследуемый исторический материал.

Исследовательница отмечает, что климатические условия Новой Англии оказались для переселенцев экстремальными. Первую зиму колонисты провели в быстровозводимых жилищах, построенных по технологиям, которыми их обучили индейцы. Это были вигвамы и землянки, - сухие, теплые, но культурно чуждые эмигрантам из Европы, и потому воспринимаемые ими как временное пристанище. Пилигримы стремились воссоздать привычный «цивилизованный» уклад жизни, и с наступлением теплого сезона принялись за строительство традиционных английских домов.
В действительности, возведенные дома стали компромиссным вариантом строительных практик, устоявшихся в тех местах, откуда были родом эмигранты. Жилища плимутцев имели в основе каркас из бревен, стены из деревянных досок и соломенную двускатную крышу. Щели между досками замазывали глиной. Пол укладывали прямо на утрамбованную землю. Планировка дома представляла собой две комнаты с очагом между ними. Эти недостаточно утепленные строения были рассчитаны на менее холодную и менее продолжительную зиму.

Автор отмечает, что технологии строительства начали постепенную, неспешную трансформацию в соответствии с реальными потребностями колонистов. Наряду с климатическими факторами этому способствовало постепенное рассредоточение поселенцев в регионе, полном свободной земли. Итогом расселения колонистов становится появление обособленных домохозяйств, ориентированных на длительное изолированное проживание.

Крыши домов стали покрывать деревянной черепицей, стены - обшивать вагонкой. Пол стал теплее за счет глубокого подпола, защищающего от промерзшей земли. Фасады домов ориентировали на юг, а к северной части дома пристраивали помещение для хозяйственных нужд, объединенное с основным строением удлиненной крышей. Именно это нововведение делало дом внешне похожим на короб для хранения соли.

Сдерживающим фактором в эволюции домостроений, по мнению Стин, являлись консервативные представления колонистов о подобающем устройстве жилища цивилизованного человека. Дома нового типа окончательно утверждаются в строительной практике только спустя восемьдесят лет с момента высадки первых поселенцев [20. Р. 54]. Тем не менее эта эволюция и разрыв со строительной практикой метрополии были наглядным свидетельством растущего самоопределения жителей Новой Англии. Опыт анализа трансформации жилищ, демонстрация процесса «акклиматизации» англичан и индивидуализации жизни поселенцев в тесной связке с природными условиями позволяет выявить новые грани формирования американской идентичности.

Еще одним вектором экологической истории Нового Плимута стала история болезней. О роли эпидемий в мировой экосистеме писал Э. Ле Руа Ладюри: «...микробная унификация мира, свершившаяся не без жертв в период между 1300 г. и 1650 г., явилась одним из наиболее мощных факторов стабилизации нашей экосистемы, произошедшей между двумя этими датами» [2. С. 162]. В истории ранних новоанглийских поселений изучение болезней привело к полемике вокруг череды эпидемий, поразивших коренных американцев накануне и в первое столетие после высадки английских переселенцев.

В 2008 г. вышла статья Кристобаля Сильвы «Чудотворные болезни: эпидемиология в колониальном ландшафте Новой Англии» [21], которая стала основой 
более объемной его работы «Чудотворные болезни: эпидемиология в нарративе ранней Новой Англии» [22]. Сильва локализует свое исследование болезней на территории первых новоанглийских поселений в период с 1616 по 1712 г. Автор сосредоточил внимание не столько на причинах эпидемий и их характере, сколько на том, как эпидемический фактор отразился на формировании идентичности колонистов сквозь призму созданных ими текстов [Ibid. P. 4].

Сильва, оговаривая рамки употребления им термина «эпидемиология», уточняет, что к корпусу источников он относит все тексты, созданные колонистами, в которых, независимо от медицинских или научных притязаний, содержится этиология болезни и объяснение механизма ее действия [Ibid. P. 10]. Сильва полагает, что эпидемия чумы, поразившая индейцев в 16161619 гг., способствовала не только успешному расселению англичан на пустых землях, но и помогла легитимировать английскую колонизацию региона. Ему удалось проследить в сочинениях колонистов устойчивое убеждение в том, что уязвимость коренного населения перед лицом болезни стала выражением божественной воли, предопределившей эти земли для проживания англичан.

Риторика пуританизма, которая подчеркивала превосходство физиологии выходцев из Старого Света, переживает кризис в середине века. В это время циклы эпидемий чумы поразили и белое население колоний. Болезням оказались подвержены, прежде всего, дети и молодые люди, рожденные после переселения в Северную Америку. Это привело к дискуссии среди религиозных лидеров переселенцев о снижении тонуса веры у второго и третьего поколений колонистов, чем и объяснялось постигшее их божье наказание.

Таким образом, эпидемиологический дискурс обретает новые грани. Развернутый в пространстве религиозных убеждений, он начинает служить политическим целям в период борьбы с антиномизмом², который в сочинениях лидеров пуритан описывается в терминах смертоносной болезни, поразившей церковь: «чума», «гангрена», «проказа». Порицалось поведение, способствующее развитию болезни, будь то реальной или метафорически обозначенной. Представив антиномизм «эпидемией», пусть и фигурально, духовные авторитеты протестантов развернули траекторию дискурса в пуританской эпидемиологии с Божьей Благодати на Божий Гнев.

Сильва утверждает, что эпидемии не воспринимались колонистами-пуританами в качестве ограниченного во времени и пространстве явления из области медицины. Болезни сохранялись в умах поселенцев в качестве образа Божьего Бича даже спустя длительное время после их завершения, влияя на формирование коллективной идентичности.

Для выявления взаимосвязи между «иммунологией» и идеологией в формировании общинной идентичности Сильва вводит в исследование понятие «воображаемый иммунитет» - совокупность представлений индивидов о том, что они являются частью сообщества, которое характеризуется наличием коллективной резистентности к определенным заболеваниям. Эти иммунные связи, «будучи формализованы профессиональными и непрофессиональными эпидемиологами, превращают отдельные социальные группы в «мистически объединенную биологическую сущность», примером которой является нация» [22. Р. 8]. Колониальное общество, оперируя категорией «воображаемого иммунитета», делится на здоровое «мы» и больное «они». Этими «они» на разных этапах выступали как индейцы, так и инакомыслящие сограждане, чьи идеи выглядели опасными в глазах духовных и светских властей. Впоследствии «воображаемый иммунитет» стал активной составляющей националистической риторики колонистов.

Избрав в качестве ключевой задачи интерпретацию пуританской мысли с позиций истории болезней, Сильва видит свою миссию в стремлении отодвинуть в сторону статичные модели биологической истории. Он рассуждает о демографической и поколенческой динамике, которая формировала подлинный физиологический и мнимый идеологический иммунитет в колониальном контексте [Ibid. P. 141]. Метод литературоведческого анализа, интегрированный в историческое исследование, демонстрирует новые уровни понимания наследия пилигримов. Связи между болезнями, поразившими колонии, политикой, проводимой властями и литературным творчеством поселенцев, становятся более прозрачными. Развивая вектор экоистории, работа Сильвы демонстрирует новое измерение в ментальности пилигримов и их потомков через выявление медицинских флуктуаций в текстах, созданных в первое столетие существования английских колоний в Новом Свете.

Особенностью мировосприятия новоанглийских пуритан была рационализация действительности сквозь призму библейских текстов. Священное писание, путем толкования и выстраивания системы аллегорий, становилось пособием по разумному устройству жизни. Знамения, которые пилигримы усматривали в окружающем мире, указывали им на божественное одобрение или порицание их поступков. Мэтт Коэн [23] дополняет работу Сильвы анализом рассказа Уильяма Брэдфорда ${ }^{3}$ об одном из таких «знамений». Им стало массовое появление цикад в лесах, окружавших Плимут, в 1633 г. - на тринадцатый год после основания колонии. Коэн сообщает, что цикады, «объедающие зелень и производящие оглушительный стрекот» [Ibid. P. 827], были истолкованы пуританами как символ надвигающейся катастрофы, по аналогии с нашествием саранчи в Ветхом Завете. Предчувствие беды было подкреплено предостережением, полученным от индейцеввампаноагов, о том, что вслед за насекомыми придет «моровое поветрие» - чума. Эпидемия, разразившаяся зимой 1633-1634 гг., в полном соответствии с прогнозом, стала одной из самых продолжительных и смертоносных в истории колонии. 
Живущие в тесной взаимосвязи с природой вампаноаги были знакомы с длительным жизненным циклом цикад, варьирующимся от тринадцати до семнадцати лет. Этот срок цикады практически полностью проводят под землей в состоянии личинки. Лишь к концу своей жизни взрослые особи одномоментно появляются на поверхности земли для спаривания, откладывания яиц и, в конечном счете, собственной гибели [23. Р. 828]. Предыдущее появление цикад состоялось за несколько лет до высадки пилигримов и совпало с эпидемией чумы 1616-1617 гг., обернувшейся катастрофичным уровнем смертности среди автохтонного населения Америки. Связка «цикады-чума» закрепилась в сознании индейцев, наделив этих насекомых функцией природного маркера истории. Вместе с этим, образ индейского народа, чье предсказание воплотилось в жизнь, получил в глазах пилигримов дополнительные мистические коннотации.

Восприятие индейцев колонистами, их образ, отношения между этими сообществами - насущная проблема современной американской колониальной историографии. В этом контексте выполнено исследование Дэвида С. Джонса «Рационализация эпидемий: значение и использование смертности американских индейцев с 1600 года» [24]. Работа Джонсона, как и упомянутые выше, направлена на анализ реакции европейских поселенцев и их потомков на эпидемии, вызвавших демографический коллапс среди североамериканских индейцев вскоре после начала колонизации континента. Последствия этой катастрофы отразились на всем процессе колонизации. Автора интересует то, как белые американцы-современники эпидемий объясняли проявившееся «иммунологическое неравенство» между европейцами и аборигенами. Исследование охватывает историческое пространство от череды инфекционных заболеваний в первые десятилетия колонизации Новой Англии в XVII в. до туберкулеза индейцев навахо в конце XX столетия.

«Рационализация эпидемий ограничена лишь пределами человеческого воображения», - пишет Джонсон [Ibid. P. 3]. Очевидцы зачастую генерируют переизбыток потенциальных объяснений, в которых определяются ответственные за возникновение болезни. Ими могут выступать сами больные, их генетические особенности, действия здоровых людей, или же некие внешние, по отношению к локальной общности, авторитеты, такие как государство или Бог. Выбор объяснения, как правило, отражает политические или социальные потребности общества в данный момент [Ibid. P. 4].

Автор находит подтверждение этому тезису, представляя в одной из четырех частей работы панораму взаимоотношений жителей Новой Англии. Идеи мессианства, избранности Богом служили вдохновением для новоанглийских пуритан на пути к построению идеального общества. Еще до эмиграции в колонию до них доходили сведения об американских аборигенах. Ранние экспедиции Дж. Смита, С. де Шамплена,
Р. Вайнса, Т. Дермера описывали местных жителей как людей активных, здоровых, живущих в процветающих селеньях. Пилигримы боялись столкновений с сильными соседями, что было подкреплено неудачным опытом колонии Роанок, уничтоженной индейцами вскоре после основания. В Новом Свете переселенцы-протестанты стали свидетелями быстрой и массовой гибели аборигенов от инфекционных заболеваний. Давая определение этим болезням, колонисты в своих текстах называли их чумой, оспой, лихорадкой или вовсе «неизвестной болезнью». Ошеломленные наблюдаемым упадком, пилигримы пытались оценить уровень смертности. В сведениях, сообщенных ими, депопуляция индейцев достигала 90-95\% [24. Р. 32]. Необходимость объяснения чрезвычайной индейской смертности породила в среде новоанглийских колонистов идею о божественной каре, постигшей дикарей-язычников и освободившей их земли для праведных пуритан, как уже было показано в работе Сильвы. В то время как переселенцы рационализировали эпидемии через божественное предопределение, индейцы «зеркальным» образом связывали свои болезни с появлением на континенте англичан и разрушительными действиями их Бога.

Д.С. Джонс отмечает, что одновременно с индейцами сами жители Плимута и Массачусетской колонии также находились в тяжелой ситуации. Половина плимутских поселенцев погибла в первую зиму от болезней и голода. Колония в Массачусетской бухте выжила благодаря помощи соседей и массовому притоку новых колонистов. Трактуя это как посланное Богом испытание, нацеленное на укрепление и очищение веры, колонии медленно учились выживать в сложных условиях.

По мере накопления знаний о причинах болезней и развития эпидемиологии, объяснения причин заболеваемости трансформируются. Это изменение проявляется к 1760-м гг., когда западное побережье США постигла эпидемия оспы. В течение XVIII и XIX столетий «провиденциальная теория» эпидемий заменяется на концепции, которые были основаны на социальных, поведенческих факторах или естественной предрасположенности индивида. Это изменение отражает общие тенденции секуляризации в понимании окружающего мира. Несмотря на меняющуюся рационализацию болезней, определенные закономерности были сохранены. Джонсон сообщает, что, вне зависимости от вида заболевания, будь то оспа, чума, туберкулез, хроническая болезнь сердца или диабет, индейцы объективно всегда отличались наименьшей резистентностью. Численность американских индейцев сокращалась даже в периоды, когда европейская часть населения чувствовала себя благополучно [25. Р. 703]. Джонсон критикует «биологический детерминизм», который объясняет подверженность коренных американцев заболеваниям их предполагаемыми генетическими особенностями. Он считает неполной и концепцию «эпидемий девственных земель», разработанную Уильямом Макнилом [26] и Альфредом В. Кросби [27], полагавших, что 
иммунологическая восприимчивость индейцев вызвана отсутствием у их иммунной системы опыта столкновения с типичными для европейцев заболеваниям, принесенными колонистами в Новый Свет. Джонсон акцентирует тот факт, что иммунитет индейцев была дополнительно угнетен недоеданием, истощением и стрессом, вызванными колонизацией. Эпидемии снижали экономическую производительность, порождали голод, делая выживших после перенесенной болезни уязвимыми перед лицом следующей инфекции. Новые болезни, в сочетании с падением рождаемости, вооруженными столкновениями, общими социальными потрясениями, обернулись для американских индейцев демографической катастрофой.

Исследование истории первых колониальных поселений в фокусе экоистории заполняет лакуны в про- странстве репрезентаций прошлого. Экосистемы сложны для изучения, поскольку связи, сложившиеся в них, часто являются опосредованными, нелинейными и неочевидными. Представленные в обзоре работы, интегрировав законы социального развития и окружающей среды, показывают историю первых колоний Новой Англии многогранной, избавляя ее от детерминизма факторов религии, политики или экономики. Сообщества колонистов Нового Плимута и Массачусетса изображены как объединения людей, чьи действия, с одной стороны, варьируются в зависимости от окружающей действительности, с другой - сами определяют ее. Подобный ракурс исторических исследований делает концепцию экологической истории востребованной и имеющей перспективы для использования в исторических работах.

\section{ПРИМЕЧАНИЯ}

\footnotetext{
${ }^{1}$ Понятие «места памяти» было введено в исследовательскую практику, начиная с коллективного проекта под руководством Пьера Нора по изучению французской национальной идентичности. Под местами памяти Нора понимал любые материальные или идеальные объекты исторического прошлого, которые по разным причинам превратились в символическую часть наследия, сохраняемую в памяти данной общности [16. C. 265].

${ }^{2}$ Антиномизм - движение в христианстве, отрицающее необходимость следования законам Священного Писания как необходимого элемента духовного спасения. Антиномиане отвергали непреложность библейских догм, полагая, что для индивидуального спасения достаточно искренней веры. С точки зрения новоанглийского пуританизма, Библия являлась прикладным сводом правил и норм поведения, организующих духовную и светскую жизнь общества. Идеи антиномизма воспринимались духовенством Новой Англии как угроза единству и благополучию общины верующих. Антиномические споры в Новой Англии 1630-х гг. были связаны с противостоянием Дж. Коттона - сторонника ортодоксального пуританизма, и Энн Хатчинсон, выступавшей против жестких церковных ограничений.

${ }^{3}$ У. Брэдфорд - второй губернатор колонии Новый Плимут (избран в 1622 г). Один из «отцов пилигримов».
}

\section{ЛИТЕРАТУРА}

1. Parsons C.M., Strang B.S. Old Roots, New Shoots: Early American Environmental History// Early American Studies. 2015. Vol. 13, № 2. P. 279-284.

2. Ле Руа Ладюри Э. Застывшая история // Thesis. 1993. Вып. 2. С. 153-173.

3. Ravi Rajan S. The Ends of Environmental History: Some Questions // Environment and History, 1997. Vol. 3, № 2. P. $245-252$.

4. Sorlin S., Warde P. Making the Environment Historical - An Introduction // Nature's End / ed. by S. Sorlin, P. Warde. London : Palgrave Macmillan, 2009. P. 1-19.

5. Turner F.J. The Frontier in American History. N.Y. : H. Holt and Company, 1920. 396 p.

6. Webb W.P. The Great Plains. Waltham; Massachusetts ; London : Blaisdell Publishing Company, 1941. 551 p.

7. Malin J.C. The Grassland of North America: Prolegomena to Its History. Lawrence, Kansas, 1947. 398 p.

8. Bell R.G. James C. Malin and the Grasslands of North America // Agricultural History. 1972. Vol. 46, № 3. P. $414-424$.

9. Бродель Ф. Средиземное море и средиземноморский мир в эпоху Филиппа П. Ч. 1: Роль среды. М.: Языки славянской культуры, 2002.496 с.

10. Ле Руа Ладюри Э. История климата с 1000 года. Л. : Гидрометеоиздат, 1971. 270 с.

11. Le Roy Ladurie E. Histoire humaine et comparée du climat. Vol. 1: Canicules et glaciers (XIII-XVIII siècles). Paris : Éd. Fayard, 2004. 748 p.

12. Le Roy Ladurie E. Histoire humaine et comparée du climat. Vol. 2: Disettes et révolutions 1740-1860. Paris : Éd. Fayard, 2006. 616 p.

13. Le Roy Ladurie E. Histoire humaine et comparée du climat. Vol. 3: Le réchauffement de 1860 à nos jours (avec le concours de Guillaume Séchet). Paris : Éd. Fayard, 2009. 462 p.

14. Le Roy Ladurie E. Trente-trois questions sur l'histoire du climat. Paris : Éd. Fayard, 2010. 192 p.

15. Cronon W. Changes in The Land: Indians, Colonists, and The Ecology of New England. N.Y. : Hill and Wang, 2003.288 p.

16. Васильев А.Г. «Места памяти» // Теория и методология исторической науки. Терминологический словарь / отв. ред. А.О. Чубарьян. М. : Аквилон, 2014. С. 263-267.

17. Бейклесс Дж. Америка глазами первооткрывателей. М. : Прогресс, 1969. 408 с.

18. Bolster W.J. Putting the Ocean in Atlantic History: Maritime Communities and Marine Ecology in the Northwest Atlantic, 1500-1800 // The American Historical Review. 2008. Vol. 113, № 1. P. 19-47.

19. DeLucia C.M. Locating Kickemuit: Springs, Stone Memorials, and Contested Placemaking in the Northeastern Borderlands // Early American Studies. 2015. Vol. 13, № 2. P. 467-502.

20. Stean M.A. Building in the Climate of the New World: A Cultural or Environmental Response? // Traditional Dwellings and Settlements Review. 2004. Vol. 15, № 2. P. 49-60.

21. Silva C. Miraculous Plagues: Epidemiology on New England's Colonial Landscape // Early American Literature. 2008. Vol. 43 , № 2. P. $249-275$.

22. Silva C. Miraculous Plagues: An Epidemiology of Early New England Narrative. N.Y. : Oxford University Press, $2011.256 \mathrm{p}$

23. Cohen M. «The Indians Told Them That Sickness Would Follow»: A Response to Miraculous Plagues // The William and Mary Quarterly. 2013. Vol. 70, № 4. P. 827-831.

24. Jones D.S. Rationalizing Epidemics: Meanings and Uses of American Indian Mortality since 1600. Cambridge, Massachusetts : Harvard University Press, 2004. 308 p.

25. Jones D.S. Virgin Soils Revisited // The William and Mary Quarterly. 2003. Vol. 60, № 4. P. $703-742$.

26. McNeill W.H. Human migration: A Historical Overview // Human migration: Patterns and Policies / ed. by W.H. McNeill, R.S. Adams. Bloomington, 1978. P. 3-20.

27. Crosby A.W. Virgin Soil Epidemics as a Factor in the Aboriginal Depopulation in America // William and Mary Quarterly. 1976. Vol. 33, № 2. P. 289-299.

Irina E. Rogaeva. Tomsk State University (Tomsk, Russia). E-mail: irina_rogaeva@mail.ru 


\section{MODERN AMERICAN HISTORIOGRAPHY ON THE COLONIAL HISTORY OF NEW PLYMOUTH AND MASSACHUSETTS IN THE 17TH CENTURY: ENVIRONMENTAL DIMENSION}

Keywords: American historiography; environmental history; New Plymouth; Massachusetts; ecosystem.

Environmental history has become a significant trajectory for the development of historical science over the past few decades. This article discusses environmental history as one of the leading research directions in modern American historiography of the first colonial settlements of New England: New Plymouth and Massachusetts.

The author identifies and characterizes key trends in modern American historiography that are aimed at studying the first English colonies in New England in the context of environmental history. The author conducts research based on the works of American historians devoted to the history of New England of the XVII century and published in the 2000-2010s.

The author demonstrates how the use of environmental history approaches allows us to interpret long-standing questions of American history: the history of relations between colonists and Indians through of their perception of the surrounding world; the genesis of colonial settlements and the evolution of architecture in the context of the climatic and geographical features of the region.

Moreover, the author shows how the use of environmental history strategies led to the emergence of fresh problematic perspectives in the study of the history of New Plymouth and Massachusetts. One of them is the history of the ocean as an integral component of a historical ecosystem. The author draws attention to how the inclusion in the panorama of the past history of the ocean made it possible to reveal the connection between the involution of the marine and coastal ecosystems of the Old World and the beginning of the development of the northeast Atlantic.

One of the directions of environmental history is the study of natural «places of memory» in the culture of the Indians, as a symbolic manifestation of the interaction between man and the environment. The author believes that the appeal to the theme of symbolic forms, which were reflected in Indian legends, contributes to the disclosure of alternative written tradition of European settlers of first colonies. Another trend in environmental history is the history of epidemics. The author notes that at present in American historiography there is a discussion around the issue of the depopulation of the indigenous population of the region, which coincided with the onset of European colonization. Today, American historians are inclined to understand epidemics as a systemic and multifactorial phenomenon, avoiding the use of deterministic concepts in their study.

Summarizing, the author concludes that the American tradition of environmental history demonstrates the successful experience of revealing hidden and implicit interconnections formed within ecosystems.

\section{REFERENCES}

1. Parsons, C.M. \& Strang, B.S. (2015) Old Roots, New Shoots: Early American Environmental History. Early American Studies. 13(2). pp. 279-284. DOI: 10.1353 /eam.2015.0010

2. Le Roy Ladurie, E. (1993) Zastyvshaya istoriya [The frozen history]. Thesis. 2. pp. 153-173.

3. Ravi Rajan, S. (1997) The Ends of Environmental History: Some Questions. Environment and History. 3(2). pp. 245-252. DOI: $10.3197 / 096734097779555908$

4. Sorlin, S. \& Warde, P. (2009) Making the Environment Historical - An Introduction. In: Sorlin, S. \& Warde, P. (eds) Nature's End. London: Palgrave Macmilla. pp. 1-19.

5. Turner, F.J. (1920) The Frontier in American History. New York: H. Holt and Company.

6. Webb, W.P. (1941) The Great Plains. Waltham, Massachusetts, London: Blaisdell Publishing Company.

7. Malin, J.C. (1947) The Grassland of North America: Prolegomena to Its History. Lawrence, Kansas: James C. Malin.

8. Bell, R.G. (1972) James C. Malin and the Grasslands of North America. Agricultural History. 46(3). pp. 414-424.

9. Braudel, F. (2002) Sredizemnoe more i sredizemnomorskiy mir v epokhu Filippa II [The Mediterranean Sea and the Mediterranean World in the Age of Philip II]. Moscow: Yazyki slavyanskoy kul'tury.

10. Le Roy Ladurie, E. (1971) Istoriya klimata s 1000 goda [Climate history since 1000]. Translated from French by A.S. Chaplygina. Leningrad: Gidrometeoizdat.

11. Le Roy Ladurie, E. (2004) Histoire humaine et comparée du climat. Vol. 1. Paris: Éd. Fayard.

12. Le Roy Ladurie, E. (2006) Histoire humaine et comparée du climat. Vol. 2. Paris: Éd. Fayard.

13. Le Roy Ladurie, E.(2009) Histoire humaine et comparée du climat. Vol. 3. Paris: Éd. Fayar.

14. Le Roy Ladurie, E. (2010) Trente-trois questions sur l'histoire du climat. Paris: Éd. Fayard.

15. Cronon, W. (2003) Changes in The Land: Indians, Colonists, and The Ecology of New England. New York: Hill and Wang.

16. Vasiliev, A.G.(2014) "Mesta pamyati" [Places of memory]. In Chubaryan, A.O. (ed.) Teoriya i metodologiya istoricheskoy nauki. Terminologicheskiy slovar' [Theory and Methodology of Historical Science. Terminological Dictionary]. Moscow: Akvilon. pp. $263-267$.

17. Bakeless, J. (1969) Amerika glazami pervootkryvateley [The Eyes of Discovery]. Translated from English by Z.M. Kanevsky. Moscow: Progress.

18. Bolster, W.J. (2008) Putting the Ocean in Atlantic History: Maritime Communities and Marine Ecology in the Northwest Atlantic, 1500-1800. The American Historical Review. 113(1). pp. 19-47. DOI: 10.1086/ahr.113.1.19

19. DeLucia, C.M. (2015) Locating Kickemuit: Springs, Stone Memorials, and Contested Placemaking in the Northeastern Borderlands. Early American Studies. 13(2). pp. 467-502. DOI: 10.1353/eam.2015.0011

20. Stean, M.A. (2004) Building in the Climate of the New World: A Cultural or Environmental Response? Traditional Dwellings and Settlements Review. 15(2). pp. 49-60.

21. Silva, C. (2008) Miraculous Plagues: Epidemiology on New England's Colonial Landscape. Early American Literature. 43(2). pp. 249-275. DOI: 10.1093/acprof:oso/9780199743476.001.0001

22. Silva, C. (2011) Miraculous Plagues: An Epidemiology of Early New England Narrative. New York: Oxford University Press.

23. Cohen, M. (2013) "The Indians Told Them That Sickness Would Follow": A Response to Miraculous Plagues. The William and Mary Quarterly. 70(4). pp. 827-831. DOI: 10.5309/willmaryquar.70.4.0827

24. Jones, D.S. (2004) Rationalizing Epidemics: Meanings and Uses of American Indian Mortality since 1600. Cambridge, Massachusetts: Harvard University Press.

25. Jones, D.S. (2003) Virgin Soils Revisited. The William and Mary Quarterly. 60(4). pp. 703-742. DOI: $10.2307 / 3491697$

26. McNeill, W.H. (1978) Human migration: A Historical Overview. In: McNeill, W.H. \& Adams, R.S. (eds) Human migration: Patterns and Policies. Bloomington: Indiana University Press. pp. 3-20.

27. Crosby, A.W. (1976) Virgin Soil Epidemics as a Factor in the Aboriginal Depopulation in America. The William and Mary Quarterly. 33(2). pp. 289-299. DOI: $10.2307 / 1922166$ 